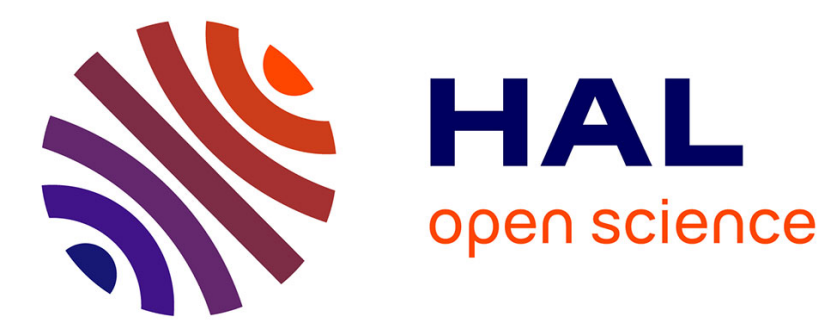

\title{
Voices into Noises: Ideological Determination of Unarticulated Justice Movements \\ Mustafa Dikeç
}

\section{To cite this version:}

Mustafa Dikeç. Voices into Noises: Ideological Determination of Unarticulated Justice Movements. Space and Polity, 2004, 10.1080/1356257042000273959 . hal-01274382

HAL Id: hal-01274382

https://hal-enpc.archives-ouvertes.fr/hal-01274382

Submitted on 15 Feb 2016

HAL is a multi-disciplinary open access archive for the deposit and dissemination of scientific research documents, whether they are published or not. The documents may come from teaching and research institutions in France or abroad, or from public or private research centers.
L'archive ouverte pluridisciplinaire HAL, est destinée au dépôt et à la diffusion de documents scientifiques de niveau recherche, publiés ou non, émanant des établissements d'enseignement et de recherche français ou étrangers, des laboratoires publics ou privés. 


\title{
Voices into Noises: Ideological Determination of Unarticulated Justice Movements
}

\author{
MUSTAFA DIKEÇ \\ [Paper first received, September 2003; in final form, June 2004]
}

\begin{abstract}
This paper looks at incidents of unrest in social housing neighbourhoods in the peripheral areas (banlieues) of French cities in the 1990s. It first focuses on the responses of the French state, and demonstrates how such areas have been constituted as 'menace' and such incidents as 'violence', through the state's discursive articulations. Then, by providing an account focused on the incidents themselves, it argues that these incidents are responses to various forms of injustice, from discrimination and police brutality to constantly increasing unemployment. They are, in other words, manifestations of contention, raising claims for justice, and not merely acts of violence.
\end{abstract}

\section{'Justice Movements'?}

This paper is not about 'justice movements'-organised or in the making-as such. It is about the responses of the French state to incidents of social unrest in the banlieues (literally, suburbs) of large cities in France in the early 1990s. Such incidents are not covered in the literature on new social movements in France (see, for example, Waters, 1998; Appleton, 1999). They are not social movements in the more conventional sense either, if one follows Buechler's definition of social movements as "intentional, collective efforts to transform social order" (Buechler, 2000, p. 213). They are neither preconceived nor organised, and they are not articulated as collective efforts aimed at transforming the established order. However, they are not intrinsic acts of violence either. They all mobilise with a demand for justice and/or as reactions against perceived injustices. 'Let justice be done' or 'J'ai la haine', ' as was heard-again-during the recent incidents in one of the banlieues of Strasbourg, following the 'accidental' killing of a person of immigrant origin by the police with a bullet in the head during a routine police road check (Libération, 22 March 2004)-a form of casualty not uncommon as the triggering incident of unrest in the banlieues (Rajsfus, 2002).

Mustafa Dikeç is in the Department of City and Regional Planning, Faculty of Architecture, Middle East Technical University, Inonu Bulvari, 06531 Ankara, Turkey. E-mail: mdikec@yahoo.com. Earlier versions of this paper were presented at the Association of American Geographers 99th Annual Meeting, New Orleans, 5-8 March 2003, and at the ISA RC21 Conference on Challenging Urban Identities, University of Milan-Bicocca, Italy, 25-27 September 2003. The author would like to thank Justin Beaumont, Claire Hancock, Walter Nicholls and two anonymous referees for comments and suggestions. 
Unarticulated as they are, such incidents are nevertheless episodic mobilisations that manifest contention and raise certain claims.

Such incidents had occurred in the banlieues before, but what makes recent years different is the changing nature of the responses of the French state to these incidents, under governments both of the Left and the Right. In the 1980s, under the Socialist government, such incidents were believed to have a political dimension. They were seen, as the former head of the 'Cities and banlieues' section at the French Intelligence Service puts it, as "a just revolt of the youth" and were addressed with policies focused more on prevention than repression (Bui-Trong, 1998b, p. 230; emphasis added). This vision, however, started to change in the 1990s, as observed by historian Eric Macé

The difference between the 90 s and the $80 \mathrm{~s}$, is that, in the 80 s ... there was a political awareness, saying: 'Deep down, these violences have a political significance. They challenge French society's ability to integrate generally'. In the 90s, under the term 'urban violence', what constitutes a threat is designated-what threatens, and what has to be intervened on, in fact, to protect us against this threat (interview in Marchands de sécurité, 2002).

Such a change in the perception of incidents taking place in the banlieues not only shadowed their political significance, but also hindered, if not completely prevented, potential political mobilisations arising from the banlieues. As a local activist from Vaulx-en-Velin, a banlieue of Lyons, put it

When there's an initiative in a banlieue, there are people, that, that in other respects you would never suspect, people who are, I don't know, members of anti-racist groups, part of movements for the defence of human rights, and who say to us, 'What you're doing is good, but it's a pity because', roughly speaking, 'There are too many foreigners in it', or else, 'You're a bit too connoted' ... It's dismaying to hear things like that! (Yves Mena, interview with the author, 23 May 2002).

Hence the title 'Voices into Noises'. My argument in this paper is that the political implications of such incidents were obscured by state-led discursive articulations of 'the banlieue', which involved the 'reconfiguration of a perceptive field' through which the banlieue-in its negatively connoted form-was provided its universe of reference. Drawing from Rancière (2000), I refer to this reconfiguration as ideological; that is, a reconfiguration of a perceptive field through the putting in place of sensible evidence, which has real effects on ways of being, saying and doing. This reconfiguration, I suggest, highlighted less the difficult material conditions in the banlieues than the threat posed by the banlieue to security and social order, rendering episodic manifestations of contention acts of violence rather than claims for justice. Hence the sub-title 'Ideological Determination of Unarticulated Justice Movements'.

My approach, then, focuses less on the ways in which collective actors articulate claims around the notion of justice (Nicholls and Beaumont, this issue) than on the state's discursive articulations that affect the ways in which claims for justice are heard-as voices or as noises. Rather than insisting on the self-evident quality of banlieues as given objects of intervention, I look at the ways in which they were constituted as objects of intervention with an associated discourse. My approach, therefore, follows in a tradition that does not 
conceive of the discursive and the non-discursive as distinct realms (Laclau and Mouffe, 1985). Such an approach maintains that objects ('the real world') do not exist independently of ideas about them and that discursive articulations have material effects in that they produce relatively stable "effect[s] of boundary, fixity, and surface" (Butler, 1993, p. 12).

This paper first illustrates the negative images associated with the banlieues, then clarifies the notion of 'statements of the state'. The following two sections focus on the responses of the French state to incidents of social unrest in the banlieues in the early 1990s and the implications of the state's discursive articulations of them. The last two sections highlight the worsening conditions in the banlieues and argue that such incidents are responses to various forms of injustice encountered by the inhabitants-from discrimination and police brutality to constantly increasing unemployment.

\section{Rearticulations}

On 4 July 1990, an article, entitled "A radioscopy of the 'fears' of the French", was published in Le Monde. Based on a study by the Institute of Interior Security Studies, the article listed the top three 'fears of the French' as drugs, AIDS and terrorism, followed by various others, one of which was 'immigrants'. What this study shows, the article argued, was that a certain consensus around the issue of security was formed in the social imaginary.

More than a decade later, during the presidential campaign, another journal, Libération, published a series of articles under the theme 'Portrait of France'. One of the series was devoted to the 'fears of the French', and listed nine issues as major objects of fear in the social imaginary (8 April 2002). The issue of security, the article argued, has become the major preoccupation of the French, before employment, which, during the presidential campaign of 1995, was the major preoccupation of the French (Le Monde, 8 March 2002). It was at the centre of Jacques Chirac's discourse on 'social fracture', a discourse which he abandoned during his 2002 campaign that was centred on the issue of 'insecurity'.

The list of Libération was not very different from the list published in 1990; there were some new entries related to contemporary phenomena-such as 'mad cow disease' and the hazards of mobile phones-and immigrants did not figure in the 2002 list. Another new entry was 'banlieue': the banlieue was one of the nine major 'phobias' of the French in the year 2002.

The change-the appearance of the banlieue and the disappearance of immigrants as objects of fear in these lists-is an important one. These lists, of course, should not be seen as transcriptions of 'reality' onto the pages of newspapers. They do not, therefore, provide the researcher with conclusions, with the necessary level of confidence to make assertions as to what has 'really' changed in French society. However, they evoke curiosity and provide the researcher with a host of questions, if not answers. Hostility towards immigrants in the French society has not decreased in the past decade. On the contrary, xenophobic reactions have increased in recent years, which is partly reflected by the rise in the popularity of the Extreme Right party National Front, which made it to the second round in the 2002 presidential elections, defeating the Socialists. Why, then, were 'immigrants' not among the major fears of the French in the latter list? Why was the banlieue on the list? It is widely known that the majority of people living in the banlieues (the ones implied by its almost pejorative sense, 
and not including the rich) are immigrants or people from immigration backgrounds. Does the banlieue represent the fear of the Other in a spatially reified form? When one expresses fears about the banlieue, does one express other fears without really talking about them? And if the banlieue is indeed the spatially reified form of the fear of the other, how did that happen and what are its political implications?

Banlieue literally means suburb, but it carries different characteristics from the ones associated with the North American suburb. Originally an administrative concept, the term 'banlieue' geographically denotes peripheral areas of large cities in general. Such a geographical designation is not necessarily negative. Nevertheless, the very term evokes an image of excluded places, as its etymological origin suggests

\begin{abstract}
'Ban' comes from the earliest medieval times, when it meant both the power of command and the power of exclusion as part of the power of command. Banned [Banni], banishment [banissement], banlieue-all these terms have the same origin; they refer to places of exclusion. Clearly, banlieues have existed independently from terms used to designate them, they have made and often managed their own history, they have not simply been excluded places, but their existence does nonetheless express this will to create on the outskirts of the city places that do not belong to the system (Paul-Levy in Banlieues 89, 1986, p. 125).
\end{abstract}

Now the term mostly evokes an image of a peripheral area with concentrations of large-scale, mostly high-rise social housing projects (referred to as grands ensembles, but also as cités and HLMs) and problems associated, in the US and the UK, with inner-city areas. In order to emphasise the differences that have to do with the implications of the term's etymological origin (excluded places) and geographical connotation (outskirts of the city), I hereafter use the term 'banlieue', instead of 'suburb', without italicising it.

Since the early 1980s, Rey (1999, p. 274) writes, the banlieues of large French cities have "arouse[d] a feeling of fear". In the social imaginary, fed partly by the media covering incidents of unrest, the banlieue figures as a threat to security, social order and peace. This threat, furthermore, has become closely associated with the populations living in banlieues, often defined in ethnic terms. The fear of banlieue is closely associated with a feeling of insecurity and a fear of immigration (Rey, 1999).

A similar observation is made by Hargreaves, who argues that the 1990s was a turning-point in the eventual association of the banlieue with a feeling of insecurity and a fear of immigration

During the 1990s, a new social space has been delineated in France: that of the 'banlieue(s)' (literally, 'suburb(s)'). A term that once served simply to denote peripheral parts of urban areas has become a synonym of alterity, deviance, and disadvantage. The mass media have played a central role in this reconstruction, in the course of which they have disseminated and reinforced stereotypical ideas of people of immigrant origin as fundamentally menacing to the established social order (Hargreaves, 1996, p. 607; emphasis added). 
Hargreaves exemplifies the media creation of 'the banlieues as a news category' amalgamating 'urban deprivation, immigration, and social disorder' in the 1990s with an issue of the journal L'Express, which presented a cover story under the title "Banlieues-Immigration: State of Emergency" (5-12 June 1991). The same journal, however, almost two decades ago, had presented another cover story on banlieues under the title "Banlieues: 'Thugs' Are Talking to You". The sub-title read: "At the gates of large cities, thousands of hoodlums are produced" (3-9 September 1973). The 'thugs' and 'hoodlums' of L'Express, as the cover drawing and the photos presented inside portray them, in 1973 were all 'White'. They would 'change colour' in 1991, but the spatial reference would remain the same and, in this sense, L'Express best exemplifies the 'changing colour' of the banlieue, of the feared outside, in the social imaginary. What happened in the 1990s, therefore, seems to be less a delineation of a new social space than a rearticulation of an already existing delineation.

Media reviews provide clear examples of the changing image of the banlieue in the past two decades (Macé, 2002; Collovald, 2000, 2001; Hargreaves, 1996). However, the current image of the banlieue is not simply the product of journalistic accounts with a greed for spectacular incidents ('riots') and catastrophic scenarios. Most of the journalistic categories used to frame banlieues were institutionalised by 'the statements of the state', notably in the 1990s, which was a period of intense discursive investment in the spatial delineations that distinguished the banlieue from the city. In this period, I would like to argue, the French state actively contributed to the rearticulation of the banlieue as a 'threat', as an object of 'fear'. It did so through the creation of new institutional structures, putting in place a series of sensible evidences, producing and putting into circulation new notions and, eventually, providing new discursive terms associated with the banlieues. The banlieue's discursive register was thus redefined through a reconfiguration of a perceptive field through the statements of the state in which the banlieue would become the spatially reified form of 'threat', notably with the rise of republican nationalism in the mid 1990s. ${ }^{2}$

\section{The Statements of the State}

States, if the pun be forgiven, state; the arcane rituals of a court of law, the formulae of royal assent to an Act of Parliament, visits of school inspectors, are all statements. They define, in great detail, acceptable forms and images of social activity and individual and collective identity; they regulate, in empirically specifiable ways, much-very much, by the 20th century-of social life. Indeed, in this sense 'the State' never stops talking (Corrigan and Sayer, 1985, p. 3).

The power of definition, as Hobbes knew, is a highly strategic power invested in the state (Connolly, 1991, p. 207).

If capitalism refers not merely to an economy, but also to regulated forms of social relations, Corrigan and Sayer (1985, p. 191) argue, then the state has an important role to play in this process, as the 'key material regulative agency' through which capitalism's wider cultural revolution is organised. The term 'cultural revolution' is intended to capture the regulated formation of identities and subjectivities, and the state-always in the making-is the major agency in this process. State formation as a process depends upon the normalising and 
rendering natural of an historically and spatially constructed social order which, in turn, serve to legitimise the state's actions. Rendering 'obvious' of the ontological and epistemological premises of a particular social order which, in fact, are contingent both historically and spatially, is the major achievement of the state and fundamental to its formation. To do that, the state needs to state. "The state's statements", however, are neither neutral nor without effect; by "defining, mapping, naming 'reality", states, in fact make claims (Corrigan and Sayer, 1985, p. 141). The state's "descriptive names (seemingly neutral, natural, universal, obvious) are in fact impositional claims" (Corrigan and Sayer, 1985, p. 7; emphasis added).

The state's self-legitimation through its 'impositional claims' and 'descriptive names' is closely linked to the establishment and reproduction of consensus. However, one should not overlook "the degree of mutuality between consensus and coercion in state formation" (Corrigan and Sayer, 1985, p. 2). The state, for one thing, has an important role to play in the constitution and regulation of social identities and, therefore, (political) subjectivities. What the state is and what it does are important. But equally important is what it says, what it states. The statements of the state have the force of law, power of designation, constitution and regulation; they not only normalise and render 'obvious' certain definitions and designations, but also materialise them.

Out of the vast range of human social capacities-possible ways in which social life could be lived-state activities more or less forcibly 'encourage' some whilst suppressing, marginalizing, eroding, undermining others. Schooling for instance comes to stand for education, policing for order, voting for political participation. Fundamental social classifications, like age and gender, are enshrined in law, embedded in institutions, routinized in administrative procedures and symbolized in rituals of state. Certain forms of activity are given the official seal of approval, others are situated beyond the pale. This has cumulative, and enormous, cultural consequences; consequences for how people identify (in many cases, have to identify) themselves and their 'place' in the world (Corrigan and Sayer, 1985, p. 4).

My approach, then, focuses on the statements of the state and the ways in which they become part of the ideological project of configuring a perceptive field and thus of affecting ways of being, saying and doing. The statements of the state are not produced in a vacuum. And once they are produced, once a relatively dominant perceptive field has been organised (which itself is an ideological achievement), what is produced at the same time is not merely a world of words and rhetoric, but ways of seeing, doing and being-in short, a world of sensibilities. It is in this world of sensibilities that solutions are proposed and justified accordingly to the problems (re)constituted in the new perceptive field. State statements, therefore, are embedded in the everyday lives of people and affect them once they are (re)formulated. They, in other words, have real effects: "What is defined as real (which is not to say the definitions are uncontested) is real in its consequences" (Corrigan and Sayer, 1985, p. 142).

Such an approach, however, carries the risk of giving too much unity to the state; after all, governments change and there are different political orientations among the agents that are part of state institutions, which do not necessarily work as parts of a perfectly coherent and integrated whole. There is, however, 
an aspect of the state that makes it possible to study the state's statements and policies, which is not its unity, but its continuity as an eminent source and power of definition and designation, both quantitatively (a 'talkative' actor) and qualitatively (an authoritative and legitimate actor). The representations, designations, definitions - in sum, the statements of the state-continue to be highly effective tools (if not the only ones, and if not uncontested) in orienting actions and practices. They also affect, as I suggested in the introduction, the ways in which claims for justice are heard. It is now to these statements that I turn, recapitulating some of the major responses of the French state to the incidents of unrest in the banlieues in the early 1990s.

\section{Reconfigurations}

I was lucky enough, a few years ago, to go to the US and the UK to work on these issues of security policy, and I came back with a few experiences in mind. I came back with the experience of curfews: 280 cities in the US had set up curfews for teenagers. I came back with the experiences around cameras, camera systems to control inner cities in particular. I also came back with those ideas and policies set up around the private cities, the gated communities. I also came back with these expanding ideas about private police, the privatisation of private [sic] police, the development of private security, with the development of Giuliani's zero tolerance policy in New York, too. All these things, ten, five years ago, would have been unthinkable in France. Now they exist. (Luc Gwiazdzinski, urban planner; interview in Marchands de sécurité, 2002)

Since the early 1980s, two issues, among others, have largely occupied the agenda of policy-makers and the larger public in France: the immigration question and incidents of social unrest in the banlieues. An urban policy programme-based on the spatial delimitation and designation of 'priority neighbourhoods' with a focus on 'prevention'-was initiated following the incidents of social unrest in the summer of 1981-referred to as the hot summer' - that took place in the banlieues of Lyons, a few months after the Socialist government came to power. These banlieues had a huge social housing stock and contained a large proportion of foreign population and second-generation immigrants.

Similar incidents had occurred in the banlieues before. This time, however, the Left was in power for the first time in the Fifth Republic and such incidents had a particular significance, especially for the opposition Right, which had centred its critique on the issue of the 'soft' attitude of the new government towards immigration (Bachmann and Le Guennec, 1996; Mucchielli, 2001). It was a period of high political tension: the Left had come to power with projects to abolish capital punishment, suspend the expulsion of 'illegal' immigrants and give voting right to foreigners in local elections. Besides, race riots had occurred on the other side of the Channel (notably in Brixton) and their ghost was haunting the French republic.

The measures taken in the early 1980s did not prevent the recurrence of incidents of social unrest in the banlieues. Between 1982 and 1989, there were five large-scale incidents of social unrest in the banlieues of large French cities 
according to a list kept by the French Intelligence Service. ${ }^{3}$ A major change would occur in the following decade.

In October 1990, furious revolts took place in Vaulx-en-Velin (a banlieue of Lyons), following the killing of a young person of immigrant origin by a police car, which was seen as 'one death too many', as the interviewed local activists put it. This was followed by another revolt in the same year and five others in the following year in various banlieues of large French cities, all with social housing and high proportions of immigrants and/or people from immigrant backgrounds. What was particularly shocking this time was that almost all the neighbourhoods where revolts occurred were sites of intervention under the urban policy (the 'priority neighbourhoods') initiated following the incidents of the early 1980s, and some were even seen as exemplary. Moreover, this series of revolts occurred in the context of hotly debated issues. The international scene was occupied with Intifada, the Salman Rushdie affair and the Gulf War. In France, there was a hot debate following the Islamic veil affair of 1989, to which the "public response was almost unanimously hostile, not to say at times hysterical" (Jennings, 2000, p. 584). The reflection of these issues in France was the development of arguments against particular communities, focusing particularly on North African immigrants and Islam as a religion. The spatial reference of such arguments was the banlieue, now accompanied by the term 'ghetto'.

The revolts of the early 1990s gave rise to five developments, which I interpret as five instances of the reconfiguration of a perceptive field by statements. These statements were directly generated by the incidents of Vaulx-en-Velin in 1990, which had become the symbol of the 'malaise of banlieues'. They were, in other words, formulated as responses to the 'malaise of banlieues', with constant references to Vaulx-en-Velin, which was its most eminent symbol.

The first of these was the creation of a City Ministry and the assignment of sous-préfets to the 'most sensitive' departments as the local arms of the central state responsible for designated neighbourhoods. This was an important statement in many ways. The major mission of the new minister for the city was defined as 'eliminating exclusion', with a focus on 400 'neighbourhoods in difficulty'. Thus, both 'the object' and 'the problem' were constituted at the same time and the creation of the new ministry suggested the presence of a 'given' problem to be tackled by the creation of a new institutional structure. This was the first instance in the reconfiguration of a perceptive field in the 1990s.

The second instance was the passing of many laws to fight against 'exclusion'. One of these laws was particularly famous, the 1991 Loi d'orientation sur la ville (LOV). Conceived to promote 'social cohesion' and avoid 'segregation', the LOV was referred to as the 'anti-ghetto' law. Like 'exclusion', 'ghettos' were now given problems-defined in ethnic terms-to be addressed by the state.

The third instance was the collaboration of the new City Ministry with INSEE (the State Statistical Institute) for profiling the neighbourhoods of intervention under urban policy and for the 'objectification' of their selection criteria. This intervention was closely related to the creation of the new City Ministry, for it constituted, spatially, its 'object'. The neighbourhoods were thus constituted as the objects of a national policy for fighting against exclusion (Estèbe, 2001), using unemployment, young people and immigrants as criteria for 'the excluded'.

The fourth instance also involved a collaboration, this time with the Ministry of Justice, presented as 'a new stage of prevention of delinquency'. In 1991, the Ministry of Justice published a document entitled 'The law acts in the city' 
(Ministère de la Justice, 1991). "The law", it was stated, was "mobilised to better respond to urban problems". There was a concern with the weakening of the authority of the law in the city ("the place of law must be reinforced in the city"). The proposal made was to have a "more direct presence of the Law [la Justice] in sensitive neighbourhoods" (a new term entering the agenda in the early 1990s, used to refer to neighbourhoods with high levels of delinquency and likelihood of rioting), with the creation-for example, of Maisons de Justice et du droit (MJD, hereafter). The MJDs were conceived to "reinforce the presence of the Law" (Ministère de la Justice, 1991, pp. 4 and 5; emphasis added) through a rapid, on the spot, treatment of delinquency in "sensitive neighbourhoods".

The fifth instance was the creation of the 'Cities and Banlieues' section at the Renseignements Généraux (the French Intelligence Service, RG hereafter) in 1991, which would specialise in 'urban violence', another new term entering the scene in the 1990s. The involvement of the RG was a strong statement, which gave the impression that the issue of 'urban violence' was a rather serious issue that had to be attended to by a state institution like the RG. The secrecy of the activities of the RG and its more traditional focus on terrorism strengthened that impression and gave even more authority to the information 'released' by the $R G$, which introduced new notions such as 'urban violence', 'sensitive neighbourhoods', 'riots' and 'urban guerrilla' into the agenda. Not only was the constant surveillance of the banlieues justified, even rendered necessary, but new ways of talking about them were also generated by the notions produced and put into circulation by the RG.

In addition to the production of new discursive terms to talk about the banlieues, the RG's involvement was also effective through the production of new statistics, with a new notion-'urban violence'. This novelty had important consequences since no statistical information had previously been gathered to measure 'urban violence'. The impression was that there was a sheer 'explosion' of 'urban violence'. These statistics were used by the media and politicians asking for more security measures without questioning their basis in fact. It was in this period that the neighbourhoods with 'bad reputation' of the 1980s became a 'menace' (Estèbe, 1999), shifting from being neighbourhoods 'in danger' to 'dangerous neighbourhoods' (Bonelli, 2001). Through such statements, the banlieue was constituted as a self-contained 'object' and then was provided with the discursive terms that linked it to issues of 'urban violence', crime, delinquency, immigration and French identity. It was placed, in other words, in a reconfigured perceptive field.

\section{A New Perceptive Field}

It is this reconfiguration of a perceptive field, of putting into place sensible evidence such as statistics, new notions and categories, that I would like to call ideological. The image of the banlieue constituted through such reconfigurations served to justify, even rendered necessary, policies of repression and constant surveillance (such as increasing and redeploying police forces, creating new police forces such as the 'proximity police', introducing new measures such as 'local security contracts', devising mechanisms for the rapid, on-the-spot treatment of delinquency, the involvement of the French Intelligence Service).

But this is only one dimension of the effects of such a reconfiguration. As the observation of an 'urban planner' presented at the start of the previous section 
suggests, (private) security measures that "would have been unthinkable in France" some 10 years ago are now thinkable, even realised. "The new El Dorado is the banlieue" (Marchands de sécurité, 2002). The 'new El Dorado' for whom?-for a relatively new sector that employs more than 100000 people, a sector that hires and advances more rapidly than the rest of the economy: the private security sector, or the 'security merchants' (marchands de sécurité), to borrow the title of the 2002 documentary by Richard Vargas. ${ }^{5}$ In 1997, the Socialist government had made the issue of insecurity its second priority after unemployment. In the framework of its programme to 'fight against insecurity', the 'proximity police' and 'local security contracts' (CLS) were implemented, starting in the same year. Since then, the banlieue has been 'the new El Dorado' for private companies offering security services, such as the preparation of 'local security diagnostics' (which is required to have a 'local security contract'), the creation of municipal police and the installation of surveillance cameras.

The reconfiguration of the perceptive field and the rearticulations of the banlieue as a 'threat' in the 1990s might account for these developments. They might also account for the different interpretations of 'riots' in the 1980s and the 1990s. In the 1980s, the incidents of unrest in the banlieues were addressed by policies of prevention and they were seen as having a political significance and not merely as intrinsic acts of violence. This interpretation is shared by the creator of the 'Cities and Banlieues' section at the French Intelligence Service, Lucienne Bui-Trong

The really critical events were the violences which took place in Vénissieux, at the Minguettes, during the summer, the summer 81 I think, but it was, they were, those violences, phenomena of degree 5 or 6 , on my scale. But still, it had already considerably impressed the ministry, well, the government, as it was a left-wing government, so that government was looking for very comprehensive solutions, and from there they launched the ... the Prime Minister Pierre Mauroy had asked Bonnemaison, the commission of mayors, to prepare a whole doctrine on that, so, it was the starting-point for the police, for urban policy, let's say, a social and comprehensive work on the neighbourhoods (Lucienne Bui-Trong, interview with the author, 6 June 2002).

This vision, however, started to change in the 1990s and policies focused more on repression than prevention while the problems in the banlieues further worsened.

\section{'Twenty Years for Unemployment, 20 Minutes for Insecurity'}

Will we be surprised each morning upon seeing the generations of the banlieues break and burn if they are told each morning that they have no chance of ever taking action in history? (Balibar et al., 1995, p. 9).

It's difficult to have a logical, general, systematic discourse about rethinking the city, while people are saying: 'Well, that's discourse and that's long term, it's to be left to academics with leisure'. We have to answer the population's claims: 'We want security, we want police, we want cameras. It works well elsewhere, so we're following suit'. And 
that can be done in 15 seconds (Luc Gwiazdzinski, Urban Planner; interview in Marchands de sécurité, 2002).

The incidents of the early 1990s generated new laws, new measures, new statistical categories; in sum, new statements. One of the stated objectives of these new statements, in the framework of urban policy, was the creation of jobs for the inhabitants of the 'priority neighbourhoods'. However, the unemployment rate in these priority neighbourhoods did not decrease. On the contrary: for the 1990-99 period, the unemployment rate in these neighbourhoods increased three times more than the national unemployment rate. Onequarter of the active population in the priority neighbourhoods ( 25.4 per cent), more than one-third of foreigners (35.3 per cent) and again more than one-third of young people aged 15-24 years (39.5 per cent) living in the designated neighbourhoods of urban policy were unemployed in 1999 (INSEE-DIV, no date).

Another increase was observed in the number of riots. Between 1982 and 1989, there were around five large-scale revolts in the French banlieues (Bui-Trong, 2000). Forty-eight large-scale riots took place in French banlieues between 1990 and 2000, not to mention a further 250 riots of a smaller scale, referred to as 'mini-riots' (la mini-émeute) (see Bui-Trong, 1993). There are common features in these 'riots' and places where they occurred. ' I have identified three.

First, all, but 2, of the areas where riots occurred are priority neighbourhoods of urban policy. Out of the 38 sites where such incidents occurred, ${ }^{8} 4$ were included from the policy's inception in 1982, 3 were included from 1983 onwards, 13 from 1984 and another 13 from 1989. All of these priority neighbourhoods experienced riots in the 1990s, after 'the return of the State'. Three of them were included in 1996, after having experienced riots and two of them have never been priority neighbourhoods.

Secondly, all the riots took place in social housing neighbourhoods with high proportions of immigrants and people of immigrant extraction, and dramatic levels of unemployment, often long-term. In terms of unemployment, the communes where these neighbourhoods are located show similar characteristics; that is, dramatically increasing levels of unemployment following the crisis of the early 1970s and the ensuing processes of economic restructuring. In 1975, the unemployment rates in these communes were slightly higher or lower than the national unemployment rate, except for a couple of cases where it was two times higher than the national unemployment rate (Toulon, 7.9 per cent, and La Seyne-sur-Mer, 7.5 per cent). After that, all of these communes were severely hit by diminishing industrial and manufacturing activities. Table 1 shows this dramatic increase in unemployment rates, first from 1975 to 1982, and then from 1975 to 1999, for the 38 communes where revolts occurred.

To give an example, in Mantes-la-Jolie (in the Paris region), included in urban policy since 1982, the unemployment rate in 1982 was 2.6 times more than that of 1975 (10.3 per cent compared with 3.9 per cent) and 5.1 times higher in 1999 (20.2 per cent) than in 1975. So for the first period, Mantes-la-Jolie is one of the 21 communes in the 2.0-2.9 range and, for the second period, one of the 6 in the 5.0-5.9 range.

As for the levels of unemployment, Table 2 below might provide some insight. This table is prepared based on the unemployment rates in the 38 communes for the census years 1975, 1982, 1990 and 1999, and shows the minimum and the 
Table 1. Unemployment rate increase for selected periods in communes where riots occurred

\begin{tabular}{ccccccc}
\hline & \multicolumn{6}{c}{ Number of communes where unemployment rate is multiplied by } \\
\cline { 2 - 7 } & $1.5-1.9$ & $2.0-2.9$ & $3.0-3.9$ & $4.0-4.9$ & $5.0-5.9$ & 7 \\
\hline $1975-82$ & 10 & 21 & 7 & - & - & - \\
$1975-99$ & - & 8 & 11 & 12 & 6 & 1 \\
\hline
\end{tabular}

Sources: Calculated from INSEE $(1990,1999)$.

Table 2. Minimum and maximum unemployment rates for selected years in communes where riots occurred (percentages)

\begin{tabular}{cccc}
\hline & \multicolumn{2}{c}{ Unemployment rate in communes } & \\
\cline { 2 - 4 } & Minimum & Maximum & $\begin{array}{c}\text { Unemployment rate in } \\
\text { metropolitan France }\end{array}$ \\
\hline 1975 & 2.6 & 7.9 & 3.8 \\
1982 & 7.0 & 15.4 & 8.9 \\
1990 & $6.6^{\mathrm{a}}$ & 20.8 & 10.9 \\
1999 & 8.6 & 24.5 & 12.9 \\
\hline
\end{tabular}

${ }^{a}$ The commune in question is Brunoy, the only one out of the 38 where the unemployment rate decreases in a given period (from 1982 to 1990), and then rises up to 9.0 per cent in 1999. Brunoy is in the department of Essonne and is a banlieue in the Paris agglomeration. The incidents had occurred in 1992 and the commune has been included in urban policy since 1996.

Sources: INSEE $(1990,1999)$.

maximum rates that are found among these communes for a given year. In one-third of the communes, more than one-fifth of the active population was unemployed in 1999. The situation is even more dramatic when the young population is concerned. Let us, again, take the example of Mantes-la-Jolie (one of the 'historical' sites of urban policy as a report qualified it) and also the commune of Garges-lès-Gonesse, both of them in the Paris region. The neighbourhood of Le Val Fourré in Mantes-la-Jolie has been included in urban policy since the policy's inception in 1982. The social housing neighbourhoods of Garges-lès-Gonesse has been included since 1984. The former experienced incidents in 1991 and the latter in 1991, March 1994, June 1994 and 1995.

As Table 3 shows, the young population is hit even more severely by increasing unemployment. To take another example, in 1999, 40.5 per cent of the active population consisting of young people aged between 15-24 were unemployed in the priority neighbourhoods of Vaulx-en-Velin. Indeed, the unemployment rates for young people in Mantes-la-Jolie and Garges-lès-Gonesse presented in Table 3 are not among the highest, although they are quite high, especially given that these have been 'priority neighbourhoods' and have been the subject of 'positive discrimination' for two decades now. When all the priority neighbourhoods of urban policy are taken into consideration, the unemployment rates of young people are higher than the figures above: 28.5 per cent for 1990 and 39.5 per cent in 1999.

What these figures suggest is that there is an embedded unemployment problem, constantly aggravating and hitting, more than any other place, the 
Table 3. Unemployment rates (percentages) and population in the urban policy neighbourhoods of Mantes-la-Jolie and Garges-lès-Gonesse, 1990 and 1999

\begin{tabular}{|c|c|c|c|c|c|c|c|c|}
\hline & \multicolumn{2}{|c|}{ Le Val Fourré } & \multicolumn{2}{|c|}{ Mantes-la-Jolie } & \multicolumn{2}{|c|}{ Neighbourhoods } & \multicolumn{2}{|c|}{ Garges-lès-Gonesse } \\
\hline & 1990 & 1999 & 1990 & 1999 & 1990 & 1999 & 1990 & 1999 \\
\hline Unemployment & 15.7 & 25.7 & 20.2 & 12.1 & 16.1 & 25.7 & 14.2 & 22.4 \\
\hline $\begin{array}{l}\text { Unemployment, } \\
15-24 \text { year olds }\end{array}$ & 24.0 & 37.7 & 32.4 & 19.5 & 25.4 & 34.6 & 23.3 & 31.3 \\
\hline Population & 25496 & & 43679 & & 66880 & & 97911 & \\
\hline
\end{tabular}

Source: INSEE-DIV (no date).

'priority neighbourhoods' in the banlieues, all of which were once working-class neighbourhoods with low levels of unemployment. These figures suggest that neighbourhoods suffer from a deeply embedded, constantly worsening unemployment problem. In this sense, 'riots' may be seen as responses to severe material conditions, experienced as persistent injustices. There is, however, more to it than that.

In stigmatised neighbourhoods, as the interviews conducted in Vaulx-en-Velin suggest, immigrants and young people of immigrant extraction, especially if they are from North Africa, suffer from racial discrimination in the job market, in relations with the police and in their political engagements (see also Wacquant, 1993). Not only, therefore, is there a discontent rising from serious material conditions, but also a feeling of resentment, which is also recognised by Bui-Trong as a major factor in riots. When asked about the major reasons for the riots, she answered the following

Riots, according to my observation, riots occur in neighbourhoods with a large population of immigrant origin, so they primarily reflect a difficulty of integration, and resentment, so, a resentment very strongly felt by young people of the second generation, and even the third generation too ... These problems are experienced as a rejection from society, and, let's say, they have the feeling they're relegated. But I think the riots, the context, the general background in which they appear, is this background, this feeling, this impression the people have of being relegated from society ... Now, incidents that trigger riots, that's another issue completely, you see, there's the triggering incident, and there's the background that's going to make it ... because incidents triggering riots are like the spark that sets fire to a stock of gunpowder, but that's what the gunpowder is. It's that resentment (Lucienne Bui-Trong, interview with the author, 6 June 2002).

The 'triggering incidents', the spark to the gunpowder, constitute the third common feature of riots. Most of these riots (34 out of 48) were provoked by the killing, accidentally or not, of a young person, of immigrant origin, of the neighbourhood in question. In 29 riots out of 48, the police are implicated (questioning, wounding or killing). This number, in fact, might be even higher. For example, the triggering incident for the 1991 riots in Le Val Fourré neighbourhood of Mantes-la-Jolie is given, in Bui-Trong's list, as a discussion over entrance to a reception given at the municipality's ice rink. But there is more to 
the story. ${ }^{9}$ After some young people, following a dispute over entry, start attacking the parked cars at the parking lot of the ice rink, the municipality calls the riot police (CRS). Someone throws a bicycle on the riot police from the sixth floor of a building, confrontations start, store windows are smashed and the commercial centre is ransacked. The riot police arrest six young people and put them in police custody. It is a Saturday night. One of these young people, an 18-year-old resident of the neighbourhood, from an immigrant background, is asthmatic, he has regularly to take medicines to prevent an attack and the cell where he is kept is far from ideal. The next day is a Sunday, so the police custody is automatically prolonged, since the courts are closed. On Monday morning, the family of the young person brings in the necessary medicines to the police station, but they are not allowed to give them to him since the medicines are not accompanied by the appropriate medical certificates and necessary official authorisations. Shortly after, the young person has an attack of asthma. He is transferred to the hospital, but it is too late. He dies. 'Spark to the gunpowder': 'riots' start and continue for two days.

This account suggests that the police might be implicated more than the list suggests. In addition to this, there are some curious incidents that call into question the practices of the police. Two of the 'riots', for example, start following the killing of two people in the police station. Another one starts after a police officer shoots and kills a young person of immigrant origin 'while trying to prevent him from committing suicide'. To give yet another example, on one occasion the spark to the gunpowder is discharged by a 'mother of a drug dealer', who 'throws herself out of the window' while the police are searching the premises. This is not to imply that the list of Bui-Trong provides false or distorted accounts. Some of the accounts, however, evoke curiosity as to the practices of the police, which I identify as the third common feature of riots.

These features of the riots of the 1990s culminate in another common aspecttheir political (in)significance, with which I conclude.

\section{Conclusions}

What is an ideology without a space to which it refers, a space which it describes, whose vocabulary and links it makes use of, and whose code it embodies? ... What we call ideology only achieves consistency by intervening in social space and in its production, and by thus taking on body therein. Ideology per se might well be said to consist primarily in a discourse upon social space (Lefebvre, 1974/1991, p. 44).

None of these riots in the 1990s has been considered to be concealing important political claims and attempts to address major, persistent injustices, and this, as we have seen, is a major difference in the responses of the French state to incidents of unrest compared with the 1980s. The stigmatising effects of having an address in the banlieue have long been observed by many scholars. Furthermore, there is evidence that police repression is somewhat 'targeted' at certain neighbourhoods classified as 'sensitive neighbourhoods'. In January 2002, the Human Rights League, the Union of Magistrates and the Union of Attorneys of France formed a commission of inquiry to address this issue (Le Monde, 20 April 2002, p. 11). The state, however, responded to the incidents of unrest in the banlieues in the 1990s by reconfiguring a perceptive field through the introduc- 
tion of 'urban violence' and 'riots' into the agenda, officially inscribing the dualism of city versus banlieue, tightening security measures and declaring its commitment to 'restoring the republican order'. With a discursive space of a particular sort constituted around the banlieues, using a vocabulary of 'urban violence' and 'riots', repression became a focus-and 'legitimately' so-whereas the focus, in the early 1980s, was on 'prevention'. However, the account I have tried to provide above suggests the possibility of interpreting 'riots' not as intrinsic acts of violence, but as, precisely, responses to grave material conditions, conditions that are constantly produced and reproduced. There is no doubt that riots are also marked with elements of violence. However, they are not just looting and burning; they connect to larger dynamics.

And there is a strong spatial dimension to this-a spatiality that contributes to the domination and oppression of inhabitants living in these areas. As many scholars working on the banlieues have observed, while socioeconomic conditions are an important factor, it is mostly a deep feeling of injustice that led to the explosion of incidents of unrest (Begag, 1990; Dubet and Lapeyronnie, 1992; Esterle-Hedibel, 2002; Jazouli, 1992; Lapeyronnie, 1995; Wieviorka et al., 1999). ${ }^{10}$ They are, in a sense, responses to spatial injustices, and they might be seen as unarticulated movements of justice for they are manifestations of dissensus addressing at once material, categorical and political conditions that are, among other factors, spatially produced. The element of (spatial) injustice follows not only from economic difficulties that keep the inhabitants 'trapped in space' (Harvey, 1989), or 'chained to a place' (Bourdieu, 1999), but also from the discursive constitution of the banlieue. As Wacquant argues

The powerful stigma attached to residence in the bounded and segregated spaces, the 'neighbourhoods of exile', ... is arguably the single most protrusive feature of the lived experience of those assigned to, or entrapped in, such areas (Wacquant, 1993, p. 369; emphasis removed).

Spatial stigmatisation is part of the daily lives of the inhabitants, youth in particular, of banlieues. Where they live becomes, in a negative way, a defining feature of their place in the society.

Furthermore, this spatial stigmatisation, intensified by the statements of the state, debilitates potential movements of justice rising from the banlieues; first, by legitimising repressive measures and surveillance techniques and, secondly, by turning political claims into disturbances; by turning, in other words, voices into noises. By confining the 'Other' into a geographical elsewhere, by closing the banlieue in itself, this strategy not only removes from perspective the structural dynamics of persistent inequalities (defined now as 'exclusion'), but also reconfigures the 'givens' of the situation by representing the banlieue in itself as a problem, treating the claims coming from the banlieues not as voices that question the order of things, but as noises that disturb the established order. As a local activist from Vaulx-en-Velin puts it

Are we going to go on this way with millions of citizens excluded from the system, and just make do with it, with impressive police forces, even the military, to contain these areas and keep these territories well delimited in public space, and where serious crises like riots, and so on, are not considered as political acts, in the sense that they result from a socio-political problem, but are seen only in terms of security and 
repression? (Pierre-Didier Tchétché-Apéa, interview with the author, 26 April 2002).

This delimitation of banlieues in public space is ideological in that it involves, to follow Lefebvre's remarks with which this section opens, a discursive reconfiguration of social space. This spatial configuration conditions perceptions of lack and surplus ('too many immigrants'; 'not enough repression') and, in so doing, it reconfigures the thresholds of toleration, terms of recognition or reject and perceptions of the 'whole' and its 'parts'. Ideological reconfiguration of a perceptive field plays on sensibilities and may easily reify an identified lack or surplus as an object of fear and threat in the social imaginary. It establishes the terms of a discourse with which problems are identified, solutions shaped, measures legitimised, and claims articulated. This social space, however, is not naturally given, although it may seem to be naturalised. The sheer contingency of the established order may be questioned by opening up new discursive spaces organised around different discursive terms, which could form the basis of new political formations that act on the established order of things by organising around a vocabulary of justice and equality.

\section{Notes}

1. Literally 'I got the hate'; this phrase is shorthand for the rebellion of the youth of the banlieues, as illustrated in the movie La Haine (Hate) by Mathieu Kassovitz (1995).

2. On the rise of republican nationalism in the 1990s, see, among others, Balibar (2001), de Rudder (2001), de Rudder and Poiret (1999) and Tévanian and Tissot (1998).

3. The list of riots is kept by the 'Cities and Banlieues' section at the French Intelligence Service, which I was told, was not even released to the press. Later, however, Lucienne Bui-Trong (the creator and head, until her retirement in 2001, of the section) kindly agreed to provide me with a copy of the list of large-scale riots (degree 8, according to her scale), which also includes information on the 'triggering incidents' and circumstances. I would like to acknowledge my gratitude to her for providing me with this information.

4. Wacquant $(1992,1993)$ has effectively shown that the use of the term 'ghetto' was 'imported' from the US, and that using the term in the French context to imply the same conditions would be deceptive. Furthermore, other statements of the state - statistics - sharply contradicted the ghetto image by demonstrating that the neighborhoods of urban policy were neither ethnically homogeneous nor large enough to function as self-contained segregated areas (see, for example, Champion et al., 1993; Champion and Marpsat, 1996).

5. I would like to express my gratitude to Walter Nicholls for bringing this documentary to my attention, and to Richard Vargas and Coup d'œil Productions for providing me with a copy and transcript.

6. During one of my visits to the neighborhood of Mas du Taureau in Vaulx-en-Velin, after the new Minister of the Interior Nicolas Sarkozy had announced the new repressive measures, one of the young inhabitants of the neighborhood, with whom I was having lunch, had this to say (and I am citing from memory): "They couldn't find a solution to unemployment for 20 years now, but they've found the solution to insecurity in 20 minutes". Sarkozy's new measures include more authority to the police, prohibition of the gathering of young people in the halls of buildings and the provision of 'flash-ball' guns, shooting plastic balls, to police officers in the 'sensitive neighbourhoods', thus enabling them to shoot 'delinquents' without killing them.

7. The analysis is based on the list of large-scale riots provided by Lucienne Bui-Trong.

8. This number seems contradictory given that there were 48 incidents. Some communes, however, experienced incidents more than once, so while the number of incidents is 48 , the number of communes where they occurred is 38 .

9. This account is based on Bachmann and Le Guennec (1996, pp. 445-446) and Jazouli (1992, pp. 153-154). 
10. Jazouli (1992, p. 169), for example, writes that young people, particularly of North African origin, constantly suffer from discriminatory practices and develop "a particular sensitivity towards injustice".

\section{References}

Appleton, A. (1999) The new social movement phenomenon: placing France in contemporary perspective, West European Politics, 22(4), pp. 57-75.

BaChmann, C. and Le GuENneC, N. (1996) Violences urbaines: Ascension et chute des classes moyennes à travers cinquante ans de politique de la ville. Paris: Albin Michel.

Balibar, E. (2001) Nous, citoyens d'Europe? Les frontières, l'Etat, le peuple. Paris: La Découverte.

Balibar, E. ET AL. (1995) La vérité?, Le Monde, 13-14 August, p. 9.

Banlieues 89 (1986) De la démocratie urbaine. Premières Assises d'Enghien 5, 6, 7 décembre 1985. Paris: Murs, Murs.

BEGAG, A. (1990) La révolte des lascars contre l'oubli à Vaulx-en-Velin. Les Annales de la recherche urbaine, 49, pp. 114-121.

BonelLi, L. (2001) Des quartiers en danger aux "quartiers dangereux", Le Monde diplomatique, February, pp. 18-19.

Bourdieu, P. (1999) Site effects, in: P. Bourdieu ET AL. (Eds) The Weight of the World: Social Suffering in Contemporary Society, trans. by P. P. Ferguson et al., pp. 123-129. Stanford: Stanford University Press.

Buechler, S. (2000) Social Movements in Advanced Capitalism: The Political Economy and Cultural Construction of Social Activism. Oxford: Oxford University Press.

Bui-Trong, L. (1993) L'insécurité des quartiers sensibles: une échelle d'évaluation, Les Cahiers de la sécurité interieure, 14, August-October, pp. 235-247.

Bui-Trong, L. (1998a) Les violences urbaines à l'échelle des renseignements généraux: un état des lieux pour 1998, Les Cahiers de la sécurité interieure, 33, pp. 215-224.

Bui-Trong, L. (1998b) Sur quelques secrets de fabrication.. Entretien avec Lucienne Bui-Trong, Les Cahiers de la sécurité interieure, 33, pp. 225-233.

Bui-Trong, L. (2000) Violence urbaine dans les quartiers sensibles, in: M.-F. MatTei and D. PuMAIN (Eds) Données Urbaines 3, pp 123-36. Paris: Anthropos.

Butler, J. (1993) Bodies That Matter: On the Discursive Limits of 'Sex'. London: Routledge.

ChAmpion, J.-B. and MARPSAT, M. (1996) La diversité des quartiers prioritaires: un défi pour la politique de la ville, Economie et Statistique, 294/295, pp. 47-65.

CHAMPION, J.-B. ET AL., (1993) Les quartiers 'en convention', Regards sur l'actualité, 196 (December), pp. 19-28.

Collovald, A. (2000) Violence et délinquance dans la presse. politisation d'un malaise social et technicisation de son traitement, in: F. BAIlleau and C. GoRgEON (Eds) Prévention et sécurité. Vers un nouvel ordre social?, pp 39-53. Saint-Denis La Plaine: DIV.

Collovald, A. (2001) Des désordres sociaux à la violence urbaine, Actes de la recherche en sciences sociales, 136/137(March), pp. 104-113.

Connolly, W. E. (1991) Identity/Difference: Democratic Negotiations of Political Paradox. Ithaca, NY: Cornell University Press.

Corrigan, P. and SAYER, D. (1985) The Great Arch: English State Formation as Cultural Revolution. Oxford: Basil Blackwell.

DE RUdDER, V. and POIRET, C. (1999) Affirmative action et 'discrimination justifiée': vers un universalisme en acte, in: P. DewitTe (Ed.) Immigration et intégration: l'état des savoirs, pp. 397-406. Paris: Editions la découverte.

Dubet, F. and Lapeyronnie, D. (1992) Les quartiers d'exil. Paris: Seuil.

EstÈBe, P. (1999) L'usage des quartiers. Action publique et géographie dans la politique de la ville (1989-1998). Unpublished PhD thesis. Université de Parix X-Nanterre.

EsTÈBE, P. (2001) Instruments et fondements de la géographie prioritaire de la politique de la ville (1982-1996), Revue française des affaires sociales, 3, pp. 25-38.

Esterle-Hedibel, M. (2002) Jeunes des cités, police et désordres urbains, in: L. MucchiELLi and

P. Robert (Eds) Crime et sécurité. L'état des savoirs, pp 376-385. Paris: La Découverte.

Hargreaves, A. G. (1996) A deviant construction: the French media and the 'Banlieues', New Community, 22(4), pp. 607-618.

HaRveY, D. (1989) The Urban Experience. Baltimore, MD: Johns Hopkins University Press.

INSEE (1990) Recensement général de la population, 1990. Paris: INSEE.

INSEE (1999) Recensement général de la population, 1999. Paris: INSEE. 
INSEE-DIV (no date) Fiches Profil-Quartiers de la politique de la ville: Données des recensements de la population de 1990 et 1999. (CD-ROM). INSEE-DIV.

JAzOUli, A. (1992) Les années banlieues. Paris: Seuil.

JENNINGS, J. (2000) Citizenship, republicanism and multiculturalism in contemporary France, British Journal of Political Science, 30(4), pp. 575-597.

LaClau, E. and Mouffe, C. (1985) Hegemony and Socialist Strategy: Towards a Radical Democratic Politics. London: Verso.

LAPEYRONNIE, D. (1995) La politique de la ville et la répresentation des populations, Problèmes economiques, 2, 418, pp. 14-16.

Lefebvre, H. (1974/1991) The Production of Space. Cambridge, MA: Blackwell.

MACÉ, E. (2002) Le traitement médiatique de la sécurité, in: L. MuCCHIELLi and P. RobERT (Eds) Crime et sécurité. L'état des savoirs, pp. 33-41. Paris: La Découverte.

Marchands de sécurité (2002) (Programme transcript), directed by Richard Vargas, produced by Coup d'œil productions.

Ministère De La Justice (1991) La justice agit dans la ville. Paris.

Mucchielli, L. 2001 Violences et insécurité: Fantasmes et réalités dans le débat français. Paris: La Découverte.

RAJSFUS, M. (2002) La police et la peine de mort: 1977-2001 = 196 morts. Paris: L'Esprit frappeur.

RANCIÈRE, J. (2000) Dissenting words: a conversation with Jacques Rancière, diacritics, 30(2), pp. 113126.

ReY, H. (1999) La peur des banlieues, in: P. DewITTE (Ed.) Immigration et intégration: l'état des savoirs, pp 274-78. Paris: Editions la découverte.

RUdDER, V. DE (2001) Politiques d'immigration' en Europe: du principe d'hospitalité à la règle d'inhospitalité VEI Enjeux, 125 (June), pp. 24-33.

Tévanian, P. and Tissot, S. (1998) Mots à maux: Dictionnaire de la lepénisation des esprits. Paris: Editions Dagorno.

Wacquant, L. (1992) Pour en finir avec le mythe des 'cités-ghettos': les différences entre la France et les États-Unis, Annales de la recherche urbaine, 52, pp. 20-30.

WACQUANT, L. (1993) Urban outcasts: stigma and division in the black American ghetto and the French urban periphery, International Journal of Urban and Regional Research, 17(3), pp. 366-383.

WATERS, S. (1998) New social movement politics in France: The rise of civic forms of mobilization, West European Politics, 21(3), pp. 170-186.

Wieviorka, M. ET AL. (1999) Violence en France. Paris: Seuil. 